\title{
Prevalence and Risk Factors of Repeat Breeding in Commercial Dairy Farms of Chittagong District of Bangladesh
}

\author{
Nath $\mathrm{BK}^{1 *}$, Das $\mathrm{BC}^{2}$, Bari $\mathrm{MS}^{1}$ and Rahman $\mathrm{MA}^{2}$ \\ ${ }^{1}$ Department of Dairy and Poultry Science, ${ }^{2}$ Department of Medicine and Surgery, Faculty of \\ Veterinary Medicine, Chittagong Veterinary and Animal Sciences University, Chittagong, \\ Bangladesh.
}

[Received: May 13, Accepted: June 02, 2014]

\begin{abstract}
The study was conducted to measure the prevalence of repeat breeding cows and to identify the potential risk factors of Repeat breeding syndrome in commercial dairy farms at Chittagong of Bangladesh during July 2011 to October 2012. A total of 15 government registered dairy farms having 283 cows were surveyed for individual and farm level variables identified using preset questionnaire. Out of them 56 dairy cows was sampled for bacteriological exploration and culture sensitivity test. Overall prevalence of repeat breeder cow in commercial dairying of Chittagong was $11.3 \%$. The univariate analysis screened potential cow level exposure high yielding cows ( $\mathrm{p}=0.02)$ and cows having peripartum events (dystocia) in last calving $(\mathrm{p}=0.001)$. Among farm level exposures, owner educational level ( $\mathrm{p}=0.05)$, nature of feed offer at farm $(\mathrm{p}=0.06)$ were evident to be potential screened factors for repeat breeding. From the 32 repeat breeders, Staphylococcus spp. 13 (40.6\%) was isolated as predominant bacteria followed by Escherichia coli 8 (25\%), Bacillus spp 6 (18.8\%), Corynebacterium spp 6 (18.8\%) and Pseudomonas spp 5 (15.6\%). The isolates of bacteria were more or less effective against eight antibiotic agents. Gentamicin 36 $(97.3 \%)$ showed higher sensitivity followed by ceftriaxone $33(89.2 \%)$, chloramphenicol $33(89.2 \%)$ indicates the effectiveness of these antibiotics in treating repeat breeding. Moreover, the identified potential risk factors should be controlled to minimize the economic loss of dairy farms.
\end{abstract}

Key words: Repeat breeding, risk factors, uterine microorganisms and antibiotic sensitivity test.

\section{INTRODUCTION}

The infertility problems in dairy cows have attracted considerable attention from dairy farmers and indeed from all whose livelihood depend on the successful and regular reproduction of farm animals. Repeat breeding (RB), defined as cows failure to conceive from 3 or more regularly spaced services in the absence of detectable abnormalities, is a costly problem for the dairy producer ${ }^{[1]}$. The causes of this type of RB might be fertilization failure and early embryonic death ${ }^{[2]}$. Non-infectious causes are bad management, chromosomal aberrations, hormonal imbalance, anatomical defects of reproductive tract, improper timing of insemination, inadequate estrus detection, improper semen handling, infertile bulls, poor nutrition and heat stress ${ }^{[3]}$. Pathogenic organisms isolated from an infected uterus are found generally in livestock environments and are capable of infecting other tissues and organs ${ }^{[4]}$. Microbes may produce a marked change in $\mathrm{pH}$ of uterine and vaginal secretions, inflammation and denudation of uterine mucosa and thereby interfere with the implantation of fertilized egg ${ }^{[5]}$. There is increasingly clear evidence that chronic uterine damage in cows results from infection ${ }^{[6]}$. Bovine genital infections, either specific or non-specific in nature, account for large number of pregnancy failure in cows. Generally, non-specific infection of genitalia is considered to be the main cause of conception failure ${ }^{[5]}$. The importance of microorganisms has been recognized as one of the causes of infertility ${ }^{[5]}$. An abnormal uterine environment may cause repeat breeding and endometritis is one of the most important causes ${ }^{[7]}$. Intrauterine infusion of antibiotic during artificial insemination is the rational treatment for repeat breeding cows ${ }^{[8]}$. Antibiotic sensitivity responses need to be studied for assessing the exact response to specific antibiotic. Antibiotic sensitivity test showed moderate to high sensitivity to amoxicillin, oxytetracycline and ciprofloxacin in repeat breeding cows ${ }^{[9]}$. Unlike many parts of Bangladesh, Chittagong characterizes as a dense dairy zone and repeat breeding is one of the major constraints in profitable dairy farming but very few research works were done on RB. Considering these, the study was designed to find out the actual frequency and risk factors of repeat breeding in Chittagong region with the aims to isolate and identify bacteria those are related with repeat breeding and finally investigate the antibiotic sensitivity to suggest the treatment for the control of such type of problem.

\section{MATERIALS AND METHODS}

The study was conducted in commercial dairy farms at Chittagong of Bangladesh during July 2011 to October 2012.

\section{Selection of cows}

The reference population comprised of all commercial dairy cows under Chittagong. The 
source population of the study entails the list of registered dairy farms under the Directorate of Livestock Services, Chittagong. Farms having $\geq 10$ cows, 91 eligible study units in 15 zones (List of govt. registered dairy farms). From that 15 farms were selected for epidemiological survey and among them 14 farms were selected for sample collection. Cows $\geq 1$ parity (s) and had post partum service were considered for cow level data collection and mucus sampling. Cows reported to be normal cyclic and bacteriological incubator for 72 hours. The cultural examination of uterine discharge for bacteriological analysis was done according to the standard methods [12]. The examination followed detailed study of colony characteristics, cellular morphology and biochemical properties. The isolated organisms with supporting growth characteristics on various media were subjected to Gram's staining described by authors, motility test, and different biochemical tests described by a previous author ${ }^{[13]}$.

Table 1. Frequency of outcome (repeat breeder) and sampling frequency

\begin{tabular}{lll}
\hline Variables/ Outcome & Frequency & $\%$ \\
\hline Clinical Category (N=283) & 251 & 88.7 \\
Normal & 32 & 11.3 \\
Repeat breeder (RB) & & \\
Swab Sampling & 126 & 44.7 \\
No & 156 & 55.3 \\
Yes & &
\end{tabular}

remained sub-fertile after three inseminations were classified as repeat breeders ${ }^{[10]}$.

\section{Questionnaire design and data collection}

To acquire farm and cow level managemental, demographic, health, production and reproduction data, a structured questionnaire was constructed. The questionnaire was designed to comprise mostly closed and open ended questions to ease data processing, minimize variation, and improve precision of responses ${ }^{[11]}$. Important farm and cow level intended data were collected. Study design was Longitudinal.

Collection and Culture of Bacteriological Samples Uterine discharge samples were drawn from both normal fertile cows and repeat breeder cows with the help of a sterilized intrauterine catheter (a $10 \mathrm{ml}$ syringe and an artificial insemination catheter) using negative pressure. Mucus samples were promptly transferred into tubes containing transport media for bacteriological examination in the Department of microbiology, Chittagong Veterinary and Animal Sciences University. The samples were then placed in a thermo flask containing ice cubes and brought to laboratory within an hour after collection.

Each sample of uterine mucus earlier put into transport media was divided and inoculated separately in Nutrient agar (NA) and Blood agar (BA) to promote growth of bacteria. Each group of these media was incubated aerobically at $37^{\circ} \mathrm{C}$. The colonies on primary cultures were repeatedly subcultured by streak-plate method (Cheesbrough, 1985) until the pure culture with homogenous colonies were obtained Media such as NA, BA, Eosin methylene blue, Salmonella Shiegella agar, Mannitol salt agar were used for these repetitive sub-cultures. The aerobic culture plates were incubated at $37^{\circ} \mathrm{C}$ in

\section{In-vitro antibiotic sensitivity test}

Antibiotic sensitivity test was performed by KirbyBauer Technique described by NCCLS ${ }^{[14]}$. The results were interpreted using zone size following 24 hours of incubation at $37^{\circ} \mathrm{C}$ at aerobic condition. The following criteria will be set to record the level of sensitivity according to the NCCLS ${ }^{[14]}$. Growth inhibition zone size $<10 \mathrm{~mm}$ in diameter was defined as Resistant whereas, growth inhibition zone size $>10 \mathrm{~mm}$ in diameter was defined as Sensitive.

\section{Statistical analysis}

Data from the questionnaires and laboratory test were stored separately in the Microsoft Excel 2007® spreadsheet program before merging and exporting to STATA $11.2^{\circledR} 2011$ (Intercooled Stata 11.2, Stata Corp., College Station, texus, USA). For univariate analysis all potential cow and farm level exposures were plotted against outcome variable (1=Repeat breeder and $0=$ Normal) using $2 \times 2$ table and measures of association was determined using Chi-square test. The potential risk factors (both cow and farm level) were screened through the univariate measures of association and exposures with $\mathrm{P}$ value of $<0.15$ were considered to recruit in multivariate analysis.

\section{RESULTS}

\section{Prevalence Survey of RB cow}

Total 15 registered dairy farms were selected for the survey from A, B and C category in Chittagong citycorporation area. A total of 669 eligible adult cows were in the source population which had $\geq 1$ parity(s). Among the 669 cows 283 (42.3\%) cows were surveyed. Because, systematic random surveyed were performed i.e. every 3 rd cow in a farm were 
consider for surveyed. Sample was collected from $156(23.3 \%)$ cows. Overall prevalence of repeat breeder cow in Category $(\mathrm{A}+\mathrm{B}+\mathrm{C})$ farms in Chittagong of Bangladesh was calculated to be $11.3 \%$ (Table 1). primarily to be potential exposures which influences the frequency of RB in farm.

Some farm level exposures like owner academic qualification $(\mathrm{p}=0.05)$, drainage system at farm $(\mathrm{p}=0.04)$, visual hygienic score of cows $(\mathrm{p}=0.04)$,

Table 2. Association between RB and cow level exposures (Screening of cow-lactation level factors for RB)

Cow/individual level exposure $\quad$ Normal $\quad$ Repeat breeder $p$

Age group $(\mathrm{N}=283)$

\begin{tabular}{|c|c|c|}
\hline Up to 4 year & $50(92.6)$ & $4(7.4)$ \\
\hline$>4-5$ years & $43(86.0)$ & $7(14.0)$ \\
\hline$>5-6$ years & $54(96.4)$ & $2(3.6)$ \\
\hline$>6-8$ years & $64(83.1)$ & $13(16.9)$ \\
\hline$>8$ years & $40(86.9)$ & $6(13.0)$ \\
\hline
\end{tabular}

Lactation number $(\mathrm{N}=283)$

$\begin{array}{lll}\mathrm{LN}=1 & 42(89.4) & 5(10.6) \\ \mathrm{LN}=2 & 66(94.3) & 4(5.7) \\ \mathrm{LN}=3 & 83(86.5) & 13(13.5) \\ \mathrm{LN}=4 & 25(86.2) & 4(13.8) \\ \mathrm{LN}=5 & 35(85.4) & 6(14.6)\end{array}$

Physiologic status of cow at survey

Fresh Cyclic (On ppt heat/served)

60(98.4) $\quad 1(1.6)$

Served open (PD -ive/Yet to PD) 306(22.1)

Served-pregnant

$85(98.8)$

$1(1.2)$

Av. milk yield (lt.)/cow/day

Up to 7

$>7-11 \mathrm{lt}$

$>11-22$ lt.

Peripartum events (last calving)

$\begin{array}{lll}\text { No event } & 147(96.1) & 6(3.9) \\ \text { Dystocia } & 60(82.2) & 13(17.8) \\ \text { Uterine infection } & 24(70.6) & 10(29.4) \\ \text { Abortion } & 18(85.7) & 3(14.3)\end{array}$

Table 1 represents the frequency of $\mathrm{RB}$ and sampling. Among the total surveyed $(\mathrm{N}=283)$ cows $251(88.6 \%)$ were normal cow and $32(11.3 \%)$ were $\mathrm{RB}$ according to our case definition. Sample was collected randomly from $156(55.3 \%)$ cows (every $3^{\text {rd }}$ cow).

Univariate measures of association of Repeat Breeder with cow level exposure risk factors are shown in Table 2. It reveals that among the cow level exposures, physiologic status of cow at survey $(\mathrm{p}=0.000)$, peri-partum events $(\mathrm{p}=0.000)$ and average Milk Yield (lt.)/Cow/day $(\mathrm{p}=0.020)$ were screened types of feed offer at farm $(\mathrm{p}=0.06)$ were evident to be potential factors at univariate analysis is shown in Table 3.

\section{Bacterial flora}

Isolation and identification of organisms from mucus samples of 154 cows showed five bacterial isolates such as Staphylococcus spp. 41(26.6\%), Bacillus spp. 23(14.9\%), E. coli 26 (16.8\%), Corynebacterium spp. 7(4.5\%) and Pseudomonas spp. 6(3.9\%). The percentage of bacteria isolated in repeat breeders is shown in Figure 7. Out of the 32 repeat breeders, Staphylococcus spp. 13(40.6\%) was predominant 
followed by Escherichia coli 8(25.0\%), Bacillus spp. 6(18.7\%), Corynebacterium spp. 6(18.7\%) and Pseudomonas spp. 5(15.6\%).
Penicillin is highly sensitive to Staphylococcus spp. On the other hand Pseudomonas spp. is resistant to penicillin (Figure 2).

Table 3. Univariate association with farm level exposures (screening farm level factors for RB)

\begin{tabular}{|c|c|c|c|}
\hline $\begin{array}{l}\text { Variables/Farm level exposures } \\
\text { Length of farming (Yr.) }\end{array}$ & Normal & Repeat breeder & $\mathrm{p}$ \\
\hline $\begin{array}{l}<10 \text { Yrs. } \\
>10-15 \text { Yrs. } \\
>15-20 \text { Yrs. } \\
>20 \text { Yrs. }\end{array}$ & $\begin{array}{l}37(84.1) \\
83(84.7) \\
54(91.5) \\
77(93.9)\end{array}$ & $\begin{array}{l}7(15.9) \\
15(15.3) \\
5(8.5) \\
5(6.1)\end{array}$ & 0.15 \\
\hline $\begin{array}{l}\text { Academic qualification of owner } \\
\text { Up to Secondary } \\
\text { Higher Secondary } \\
\text { Graduate }\end{array}$ & $\begin{array}{l}48(81.4) \\
48(85.7) \\
155(92.3)\end{array}$ & $\begin{array}{l}11(18.6) \\
8(14.3) \\
13(7.7)\end{array}$ & 0.05 \\
\hline $\begin{array}{l}\text { Drainage system at farm } \\
\text { Good } \\
\text { Moderate } \\
\text { Poor }\end{array}$ & $\begin{array}{l}121(93.8) \\
85(85.0) \\
45(83.3)\end{array}$ & $\begin{array}{l}8(6.2) \\
15(15.0) \\
9(16.8)\end{array}$ & 0.04 \\
\hline $\begin{array}{l}\text { Visual hygienic score of cows } \\
\text { Clean } \\
\text { Dirty }\end{array}$ & $\begin{array}{l}171(91.4) \\
80(83.3)\end{array}$ & $\begin{array}{l}16(8.6) \\
16(16.7)\end{array}$ & 0.04 \\
\hline $\begin{array}{l}\text { Nature of feed offer at farm } \\
\text { Mostly Concentrate with Irregular Roughage } \\
\text { Sufficient Green Grass with Standard Concentrate }\end{array}$ & $\begin{array}{l}230(89.8) \\
21(77.8)\end{array}$ & $\begin{array}{l}26(10.2) \\
6(22.2)\end{array}$ & 0.06 \\
\hline $\begin{array}{l}\text { Frequency and time of feeding } \\
\text { Twice(Morning-Afternoon) } \\
\text { Twice (Morning-Evening) }\end{array}$ & $\begin{array}{l}118(91.5) \\
133(86.4)\end{array}$ & $\begin{array}{l}11(8.5) \\
21(13.6)\end{array}$ & 0.17 \\
\hline $\begin{array}{l}\text { Amount of green grass offered/day } \\
\text { Up to } 20 \\
>20 \mathrm{~kg} / \text { day }\end{array}$ & $\begin{array}{l}97(86.6) \\
154(90.1)\end{array}$ & $\begin{array}{l}15(13.4) \\
17(9.9)\end{array}$ & 0.37 \\
\hline $\begin{array}{l}\text { Inseminator type } \\
\text { FAI(Govt.) } \\
\text { Private Technician }\end{array}$ & $\begin{array}{l}166(86.9) \\
85(92.4)\end{array}$ & $\begin{array}{l}25(13.1) \\
7(7.6)\end{array}$ & 0.17 \\
\hline RFM management practice at farm & & & \\
\hline $\begin{array}{l}\text { Hormonal/Antibiotics } \\
\text { Manual Removal }\end{array}$ & $\begin{array}{l}86(86.0) \\
165(90.2)\end{array}$ & $\begin{array}{l}14(14.0) \\
18(9.8)\end{array}$ & 0.29 \\
\hline
\end{tabular}

\section{In vitro antibiotic sensitivity test}

The antibiogram of 37 uterine mucus samples indicated that gentamicin 36(97.3\%) shows higher sensitivity followed by ceftriaxone 33(89.2\%), chloramphenicol 33(89.2\%), sulphamethaxole $19(51.3 \%)$, ciprofloxacin 17(45.9\%), tetracycline 14(37.8\%), ampicillin 12(32.4\%) and penicillin $6(16.2 \%)$. All of the 4 isolates were more or less sensitive to tetracycline, gentamicin, ceftriaxone, chloramphenicol, and sulphamethaxole were shown in figure 2. It was found that out of 4 bacteria Corynebacterium spp. and Pseudomonas spp. are less effective against eight antibiotic agents.

\section{DISCUSSION}

Overall prevalence study of repeat breeder cow

The present study recorded the overall prevalence of repeat breeding cows to be found $11.3 \%$ (Table 2), which is in close agreement with the earlier findings ${ }^{[15]}$. Another studies ${ }^{[16]}$ reported $20.2 \%$ incidence of RB slightly higher than the current findings. The variations might be due to the measures used to define RB, study design, difference in geographical location, agro-climatic zones and individual variations. According to previous report in our country, 13.0 to $22.0 \%$ cows had been identified as 
$\mathrm{RB}$, of which $81.90 \%$ repeat breeding occurs due to infectious agents ${ }^{[17]}$. The present study however, has a reason to argue with earlier report, as RB cows supposed to be healthy cyclic cows and does not necessarily result from any infectious cause. With this ground in mind as the consideration and criteria for defining a repeat breeder cow as comparatively reasonable in the study, therefore the prevalence of $\mathrm{RB}$ as recorded in the present study was more acceptable and indicates the overall RB problem in commercial dairying in Chittagong.

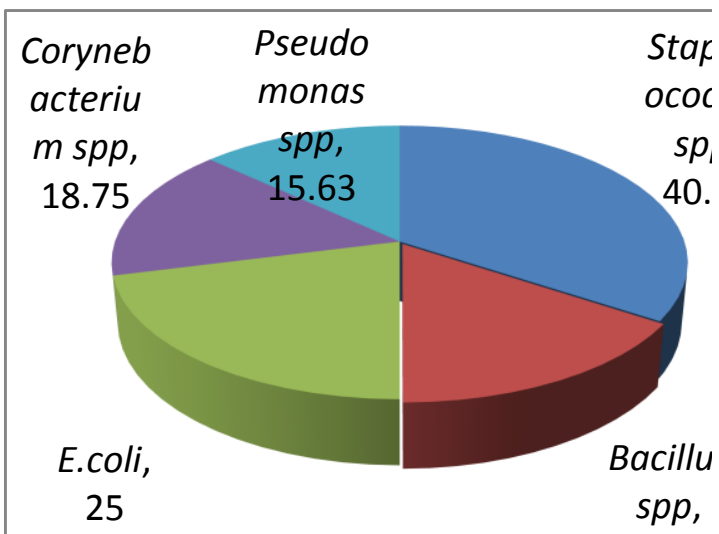

Figure 1. Percentage of isolated bacteria in RB cow

\section{Cow/individual level of risk factors for repeat breeder}

Physiologic status (Fresh cyclic/ served open) of cow at survey has significant effect $(\mathrm{p}<0.05)$ on repeat breeding which are consistent with a previous findings ${ }^{[1]}$. The study explored that the prevalence of RB was higher $(61.3 \%)$ among high yielding cows (>7-11 lt.). Milk yield has significant effect $(\mathrm{p}<0.05)$ on repeat breeding as reported elsewhere. This

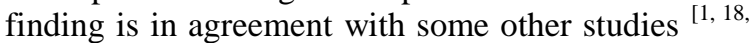
${ }^{19]}$. The study revealed that the prevalence of RB was higher among cows which had history of dystocia $(40.6 \%)$ and uterine infection (31.2\%) during last calving. Peripartum events of cows has significant effect $(\mathrm{p}<0.05)$ on repeat breeding which is close agreement with the findings of another studies $[1,20]$. The prevalence of RB was $40.6 \%$ in the age group $\geq$ 4 year and subsequently increased in the preceding lactation number. However, the association of age and lactation number with the repeat breeding was not significant $(p>0.05)$. Similar findings were also available. According to findings of a previous study ${ }^{[1]} \mathrm{RB}$ rates were more prevalent in cows 7 years of age. As it has been postulated that RB syndrome is more of managemental origin than infections therefore parity although exposes cows to infection with repeated calving and peripartum events but the exact mechanism of parity to influence RB yet to understand in greater details.

\section{Farm level of risk factors}

In this study farms having educated owner had relatively higher probability $(\mathrm{p}<0.05)$ of being repeat breeder. Low educated farm owner spent more time in farm supervision than high educated owner. Type of feed offer at farm had a significant effect $(\mathrm{p}<0.01)$ on repeat breeding. Green grass helps in folliculogenesis of ovary. $\beta$-carotene improved the pregnancy rate in $\mathrm{RB}$ cow by $33.3 \%$ compared with $27.2 \%$ in the control group which may be attributed to high oestradiol and progesterone levels resulting from increased follicle size and corpus luteum functionality [21]

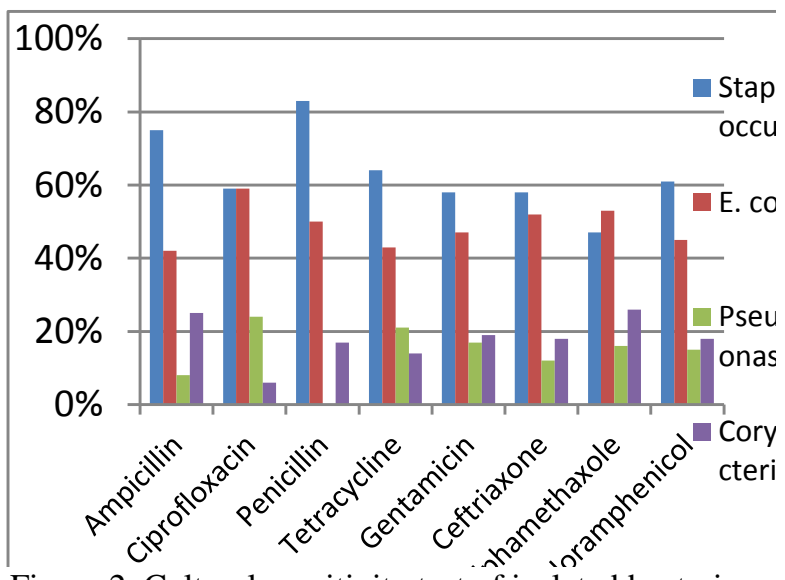

Figure 2. Cultural sensitivity test of isolated bacteria

\section{Bacterial isolation}

Isolation of Staphylococcus spp., Corynebacterium spp. and Pseudomonas spp. from cow has a significant effect $(\mathrm{p}<0.01)$ on repeat breeding. Some authors ${ }^{[8]}$ also found a positive correlation $(\mathrm{r}=0.94)$ between RB and bacterial infection of uterus. All of the five isolates were commonly found in both normal and repeat breeder cows in various proportion, which indicates that these pathogens are opportunistic to uterus. However, the presence of Staphylococcus spp., Corynebacterium spp. and Pseudomonas spp. in a higher frequency may be considered to be significant. At present study, we found Staphylococcus spp. 13(40.6\%), Escherichia coli $8(25.0 \%)$ in RB cows which in agreement with previous author ${ }^{[8]}$. We also found Bacillus spp. $6(18.7 \%)$ which in agreement with previous author ${ }^{[21]}$. On the contrary another authors ${ }^{[8]}$ found a higher percentage $(35.1 \%)$ of Bacillus spp. in RB cows. Corynebacterium spp. and Pseudomonas spp. were isolated in RB cows at $6(18.7 \%)$ and $5(15.6 \%)$, respectively which in contrary to some author [22] who isolates these two bacteria at $8(8.2 \%)$ and $6(6.2 \%)$. However it may be postulated that these anaerobic bacteria population might be correlated with the exposure of peripartum events and can interfere with the conception in RB cows with subclinical uterine infections without interrupting the normal cyclicity. However the specific role of these isolated bacteria and their exact mechanism with RB yet to clearly understand.

\section{Antibiotic sensitivity test}

In this study, the isolates of bacteria are more or less effective against eight antibiotic agents except pseudomonas spp. which was completely resistant to penicillin. On the other hand, penicillin shows higher sensitivity to Staphylococcus spp. Gentamicin $36(97.3 \%)$ shows higher sensitivity followed by 
ceftriaxone 33(89.2\%), chloramphenicol 33(89.2\%), sulphamethaxole $19(51.3 \%)$, ciprofloxacin $17(45.9 \%)$, tetracycline $14(37.8 \%)$, ampicillin $12(32.4 \%)$ and penicillin 6(16.2\%). Similar observations were found by previous authors ${ }^{[22,23]}$. Antibiotic sensitivity test was done only in aerobic condition. The sensitivity response to different antibiotics in aerobic environment studied, though the bacteria present in the uterus were of anaerobic environment. It's sensitivity response need to be studied in anaerobic condition for assessing the exact response to specific antibiotics. as suggested that penicillin and oxytetracyclin are the choice of drugs that can be used in treating uterine infections as because these antibiotics are effective in anaerobic environment of the uterus in presence of organic debris. On the other hand, another author ${ }^{[24]}$ also observed maximum sensitivity of the isolates to gentamicin, tetracycline and chloramphenicol and recommended the antibiotics for the treatment of RB cows but in this investigation tetracycline was not encountered as effective drug and resistance to tetracycline was $(62.20 \%)$. The variation in sensitivity may be related to geographical variation and injudicious use of antibiotics in a specific area. However, the result of sensitivity against the isolated bacteria flora indicated that this antimicrobial therapeutic use is more logical in treating subclinical uterine infection rather their questionable success for RB unless it's being generated of infectious origin.

\section{CONCLUSION}

In conclusion the study shows that RB in cows is a multifactorial problem involving management factors and environmental factors as well as factors coupled to the individual cow. Prevalence of repeat breeding was higher in commercial dairy farms, most likely due to intensive management system, lack of herd health approach and disease identification and eradication policy. The allied risk factors for the occurrence of RB in the study area are usually overlooked. At present study, physiologic status, average daily milk yield, types of feed offer at farm and presence of peripartum events were identified as significant risk factors of repeat breeding. The isolated bacteria have no significant effect on repeat breeding because these are the opportunistic pathogens of uterus and all of the five isolates were present in both normal and repeat breeding cows. A routine systematic collection and comprehensive analysis of reproductive data is key to determine if there is a repeat breeder problem. Strengthening estrus detection programs and correction in insemination practices, inseminator performance in handling frozen semen and deposition of semen will reduce the number of repeat breeders; however, due to the challenges of the high-producing dairy cow, further steps should be taken to improve fertility.

\section{ACKNOWLEDGEMENTS}

The author greatly acknowledge to Ministry of Science and Information, Communication Technology, Bangladesh and Department of Medicine and Surgery, CVASU, Bangladesh for financial and technical support.

\section{REFERENCES}

1. Gustafsson H, Emanuelson U (2002). Characterization of the repeat breeding syndrome in Swedish dairy cattle. Acta. Vet. Scand. 43: 115-125.

2. Amiridis GS, Tsiligianni TH, Dovolou E, Rekkas C, Vouzaras D, Menegatos I (2009). Combined administration of gonadotrophinreleasing hormone, progesterone and meloxicam is an effective treatment for the repeat-breeder cow. Theriogenol. 72: 542- 548.

3. El-Khadrawy HH, Ahmed WM, Hanafi M (2011). Observations on Repeat breeding in Farm Animals with Emphasis on its Control. $J$. Reprod. Fertil. 2: 01-07.

4. Azawi OI (2008). Review: Postpartum uterine infection in cattle. Ani. Reprod. Sci. 105: 187208.

5. Singh NP, Chaturvedi VK, Singh DP (1996). Bacteriological studies on repeat breeder bovines. Indian. Vet. J. 73: 462-463.

6. Noakes DE, Parkinson TJ, England GCW (2001). Arthur's Veterinary Obstetrics. $8^{\text {th }}$ Edition. 402-406 and 461-464, W. B. Saunders.

7. Ahmadi MR, Dehghan SA (2007). Evaluation of the treatment of repeat breeder dairy cows with uterine lavage plus $\mathrm{PGF}_{2 \alpha}$, with and without Cephapirin. Turk. J. Vet. Anim. Sci. 31: 125-129.

8. Huber WG (1982). Chemotherapy of microbial fungal and viral disease. In: John's Veterinary Pharmacology and Therapeutics. (Booth $\mathrm{NH}$, McDonald LE, eds), First Indian edn. pp: 693782, Kalyani Publishers.

9. Gani MO, Amin MM, Alam MGS, Kayash ME, Karim MR, Samad MA, Islam MR (2008). Bacterial Flora Associated With Repeat Breeding and Uterine Infections in Dairy Cows. Bang. J. Vet. Med. 6: 79-86.

10. Singh M, Pant HC (1999). Factors associated with repeat breeding in Himachal Pradesh. Indian. Vet. J. 76: 522-523.

11. Thrusfield MV (2005). Criteria for success of questionnaire. Veterinary Epidemiology, Blackwell Science, 3: 189-213.

12. Cowan ST (1985). Cowan and Steel's manual for identification of medical bacteria. $2^{\text {nd }}$ edition. 46-79, Cambridge University Press, Cambridge, London.

13. Farin PW, Ball L, Olson JD, Mortimer RG, Jones RL, Andey WS, McChesney AE (1989). Effect of Actinomyces pyogenes and Gram- 
negative anaerobic bacteria on the development of bovine pyometra. Theriogenol. 31: 979-989.

14. National Committee for Clinical Laboratory Standards (NCCLS) (2002). Performance Standards for antimicrobial suscepti bility testing. $8^{\text {th }}$ Informational Supplement. M100 S12. National Committee for Clinical Laboratory Standards, Villanova, Pa.

15. Mohteshamuddin K, Dhabale RB, Prakash N, Tandle MK, Basawaraj A (2012). Incidence of Repeat Breeding in Cattle of Bidar Taluka Karnataka, India. Int. J. Agro. Vet. Med. Sci. 6: 11-13.

16. Sarder MJU, Moni MIZ, Aktar S (2010). Prevalence of reproductive disorders of crossbreed cows in the Rajshahi district of Bangladesh. SAARC. J. Agri. 8: 65-75.

17. Samad MA (1996). Poshu Palon $O$ Chikitsavidya. $1^{\text {st }}$ edn LEP, Mymensingh, Bangladesh.

18. Bartlett PC, Kirk JH, Mather E (1986). Repeated insemination in Michigan Holstein Fresian cattle: incidence, descriptive epidemiology and estimated economic impact. Theriogenol. 26:309-322.

19. Moss N, Lean IJ, Reid SW, Hodgson DR (2002). Risk factors for repeat-breeder syndrome in New South Wales dairy cows, 54: 91-103.

20. Ariane BH, Emile B, Denis DT, Rejean L (2011). Effect of reproductive disorders and parity on repeat breeder status and culling of dairy cows in Quebec. Can. J. Vet. Res. 75: 147-151.

21. Celik HA, Avci G, Aydin I, Bulbul A, Bulbul T (2009). Effect of $\beta$ carotene on ovarian function and ovsynch success in repeat breeder cows. Kafkas. Univ. Vet. Fak. Der. 15: 87-94.

22. Kamal MM, Parveen N, Saha S, Amin MM (2001). Bacteriological Study on Uterine Discharge in Repeat Breeder Cows. Bang. J. Vet. Med. 35: 49-52.

23. Mutiga ER (1978). Treatment of the Repeat Breeder Cow Syndrome in Kenya. Trop. Anim. Heal. Prod. 10: 223-228.

24. Singh M, Sharma M, Pant HC (1998). Microbiological study on cervical mucus of repeat breeder cows in Himachal Pradesh. Indian. Vet. J. 75: 710-712. 